\title{
ANALISIS PENGARUH SUHU PENYIMPANAN TERHADAP STABILITAS SUSPENSI IBUPROFEN MENGGUNAKAN METODE HPLC (High Performance Liquid Chromatography)
}

\author{
Nurul Ulva*1, Wirasti ${ }^{2}$, Dwi Bagus Pambudi ${ }^{3}$, Khusna Santika Rahmasari ${ }^{4}$ \\ ${ }^{* 1,2,3,4}$ Universitas Muhammadiyah Pekajangan Pekalongan, Pekalongan, Jawa Tengah, Indonesia \\ e-mail: 'nurululva0702@gmail.com, ${ }^{2}$ wirasti.kharis@gmail.com, ${ }^{3}$ dwibagus589@gmail.com, \\ kㅐusnasantikar@gmail.com
}

\begin{abstract}
ABSTRAK
Ibuprofen merupakan derivat asam propionat yang berkhasiat analgetik dan antipiretik. Sifat kelarutan ibuprofen yang rendah mempengaruhi stabilitas sediaan selama penyimpanan. Penggunaan sediaan suspensi ibuprofen yang tidak langsung habis disimpan untuk digunakan kembali. Penyimpanan suspensi ibuprofen yang sesuai dengan etiket pada suhu dibawah $30^{\circ} \mathrm{C}$. Tujuan dari penelitian ini adalah untuk menganalisis pengaruh perbedaan suhu penyimpanan terhadap stabilitas sediaan suspensi ibuprofen. Metode sampel menggunakan simple random sampling. Preparasi sampel disimpan pada suhu kamar (25$\left.27^{\circ} \mathrm{C}\right)$, suhu sejuk $\left(8-15^{\circ} \mathrm{C}\right)$, dan suhu dingin $\left(4-6^{\circ} \mathrm{C}\right)$. Analisis kadar menggunakan alat HPLC ( High Performance Liquid Chromtography) dengan fase gerak metanol dan aqua bidestillata (60:40). Data yang didapat dianalisis menggunakan analisis regresi linier. Hasil pengukuran kadar dari analisis regresi linier menunjukkan penurunan kadar penyimpanan suhu kamar antara 5,2-26,49 mg, pada penyimpanan suhu sejuk antara 28,77-59,09 mg, dan pada suhu dingin antara 45,74-70,94 mg. Data penurunan kadar tersebut menunjukkan sediaan suspensi ibuprofen lebih stabil disimpan pada suhu kamar.
\end{abstract}

Kata Kunci: ibuprofen, suspense, stabilitas, suhu penyimpanan, HPLC.

\begin{abstract}
Ibuprofen is a propionic acid derivative with nalgesic and antipyretic properties. The low solubility of ibuprofen affects the stability of the preparation during storage. Use of ibuprofen suspensions that do no run out immediately for reuse. Store the labeled appropriate ibuprofen suspension at temperatures below $30^{\circ} \mathrm{C}$. The purpose of the research was to analyze the effect of storage temperature on the stability of ibuprofen suspension. The sample methode using simple random sampling. Sample preparation was stored at room temperature $\left(25-27^{\circ} \mathrm{C}\right)$, cool temperature $\left(8-15^{\circ} \mathrm{C}\right)$, and cold temperature $\left(4-6^{\circ} \mathrm{C}\right)$. The level analysis used HPLC (High Performance Liquid Chromatography) with methanol and aqua bidestillata (60 $: 40$ ). The data were analyzed using linear regression analysis. The result of measurement of levels from linear regression analysis showed a decrease in the level of storage at room temperature between 5.2-25.58 $\mathrm{mg}$, at cool temperature storage between 28.77-59.09 mg, and at cold temperature between 45.75-70.94 $m g$. The data on the decrease in levels showes that the ibuprofen suspension was more stable at room temperature.
\end{abstract}

Keyword: ibuprofen, suspension, stability, storage temperature, HPLC. 


\section{PENDAHULUAN}

Derajat keehatan anak perlu diperhatikan apabila dihadapkan pada kondisi cuaca di Indonesia dimana wabah demam menjadi penyakit yang sering ditemui pada anak-anak. Menurut penelitian oleh [1] sebanyak 10-15\% anak diperiksakan ke dokter akibat demam. Demam merupakan kondisi dimana suhu tubuh lebih tinggi dari biasanya, juga menjadi tanda adanya suatu penyakit. Suhu tubuh normal pada manusia yaitu $37,8^{\circ} \mathrm{C}$. Penatalaksanaan menurunkan panas akibat demam secara farmakologik dapat dilakukan dengan pemberian antipiretik. Obat antipiretik yang direkomendasikan untuk pediatrik yaitu paracetamol dan ibuprofen (rekomendasi A) [2].<smiles>CC(C)Cc1ccc(C(C)C(=O)O)cc1</smiles>

\section{Gambar 1. Struktur Kimia Ibuprofen}

Ibuprofen termasuk obat NSAID golongan asam propionat memiliki efek farmakologis analgetik antipiretik yang sering digunakan untuk mengatasi demam pada anak [3].ibuprofen memiliki permasalahan terhadap kelarutan dimana sifat permeabilitas tinggi dengan kelarutan yang rendah sehingga termasuk dalam karakteristik BCS (Biopharmaceutics Classification System) kelas II. Bioavailabilitas obat BCS kelas II tergantung pada jenis sediaan dan kecepatan pelepasan zat aktif sehingga pemilihan kosolven sangat penting dalam menjaga kestabilan zat aktifnya [4].

Untuk meningkatkan kelarutan ibuprofen dalam sediaan cair umumnya dikemas menjadi sediaan suspensi [5]. Permasalahan sediaan suspensi terletak pada partikel terdispersi dalam cairan pembawanya, dimana dalam kondisi penyimpanan yang tidak sesuai dapat menyebabkan pengendapan partikel (caking) baik bersifat reversibel maupun irreversibel tergantung pada laju alirnya. Kestabilan sediaan suspensi dipengaruhi oleh suhu penyimpanan. Stabilitas suspensi selama penyimpanan berpengaruh pada $\mathrm{pH}$, pembentukan caking dan kadar. Penyimpanan sediaan dengan baik dan aman menjadi mutu kualitas produk yang didistribusikan dan menjaga satbilitasnya [6]. Penyimpanan sirup suspensi ibuprofen pada suhu di bawah $30^{\circ} \mathrm{C}$ tertera pada brosur dan kemasan sediaan. Namun, beberapa masayarakat masih ada yang menyimpan obat dalam lemari pendingin atau di atas meja jika masih sisa digunakan kembali ketika dibutuhkan. Ketidaktepatan penyimpanan dapat mengakibatkan perubahan fisik pada sediaan, potensi dan kadar obat [7].

Suhu penyimpanan berpengaruh besar dalam menjaga kualitas sediaan obat selama masa penyimpanan. oleh karena itu, peneliti melakukan perlakuan suhu yang berbeda-beda yaitu tanpa perlakuan suhu, suhu kamar $\left(27^{\circ} \mathrm{C}\right)$, suhu sejuk $\left(10-15^{\circ} \mathrm{C}\right)$, dan suhu dingin atau dalam lemari pendingin $\left(4-6^{\circ} \mathrm{C}\right)$ [8]. Penelitian menggunakan metode HPLC yang lebih efisien dan spesifikasi yang tinggi sehingga hasil uji lebih akurat [9]. 


\section{METODE PENELITIAN}

\subsection{Alat dan Bahan}

Peralatan yang digunakan dalam penelitian diantaranya HPLC (High Performance liquid Cromatography) (Shimadzu SPD20A), Kolom C18 dimensi $250 \times 4,6 \mathrm{~mm}$ dan ukuran pori $5 \mu \mathrm{m}$ (YMC Triart C18), mikrofilter 0,22 dan 0,45 $\mu \mathrm{m}$, spektrofotometer Uv-Vis (Shimadzu 1280), kuvet (Shimadzu), mikropipet (Dragonlab), ultrasonikator (Merck), lemari pendingin, coolbox, neraca analitik (Ohaus), termometer (lokal), pipet volume (Iwaki), dan peralatan gelas (Pyrex). Bahan yang digunakan dalam penelitian diantaranya sirup suspensi Ibuprofen generik dan merek dagang, baku Ibuprofen p.a (Alfa Kemika), metanol pa.a (Merck KgaA 64271 Darmstad), metanol for HPLC p.a (J.T.Baker), dan aqua bidestillata (Jaya Santosa).

\subsection{Jalannya Penelitian}

\section{Larutan Baku Induk Ibuprofen}

Larutan baku induk dibuat dengan menimbang sebanyak $25 \mathrm{mg}$ baku Ibuprofen. Kemudian, dilarutkan dengan metanol pro analisa dalam labu takar $25 \mathrm{~mL}$ hingga tanda batas sehingga diperoleh konsentrasi $1000 \mathrm{ppm}(\mu \mathrm{g} / \mathrm{mL})$ dan disaring menggunakan mikrofilter 0,22 $\mu \mathrm{m}$.

\section{Pembuatan Kurva Baku}

Larutan seri konsentrasi yang dibuat 100, 200, 300, 400, dan $500 \mu \mathrm{g} / \mathrm{mL}$ diambil dari larutan baku induk Ibuprofen [10]. Kemudian, masing-masing konsentrasi larutan ditambahkan metanol pro analisa hingga tanda batas dalam labu takar $10 \mathrm{~mL}$. Kemudian disonikasi menggunakan alat ultrasonikator selama 10 menit, selanjutnya disaring menggunakan mikrofilter $0,22 \mu \mathrm{m}$. Masing-masing konsentrasi diinjeksikan ke dalam sistem HPLC dengan laju alirnya adalah $1 \mathrm{~mL} / \mathrm{min}$ dan volume injeksi yang digunakan $20 \mu \mathrm{L}$ pada panjang gelombang maksimum. Fase gerak yang digunakan merupakan campuran pelarut metanol dan aqua bidestilata dengan perbandingan 60 : 40 [10]. Fase diam yang digunakan adalah kolom C18 dimensi 250 x 4,6 mm dan ukuran pori $5 \mu \mathrm{m}$. Data puncak kromatogram dibuat kurva kalibrasi dan dihitung persamaan garis regresinya.

\section{Penentuan Panjang Gelombang}

Penentuan panjang gelombang maksimum Ibuprofen menggunakan larutan seri konsentrasi 100 dan $500 \mu \mathrm{g} / \mathrm{mL}$. Larutan konsentrasi 100 dan $500 \mu \mathrm{g} / \mathrm{mL}$ dibaca serapannya pada panjang gelombang 200-300 nm menggunakan spektrofotometer UV-Vis. Panjang gelombang maksimum dihasilkan oleh larutan yang memiliki puncak gelombang tertinggi.

\section{Preparasi Sediaan}

Sampel uji penelitian menggunakan teknik simple random sampling atau sampel acak sederhana [11]. Hasil perhitungan teknik sampel menggunakan rumus Slovin diperoleh sebanyak 2 sampel sediaan terdiri dari 1 sirup suspensi merek generik (sampel 1) dan 1 sirup suspensi merek dagang (sampel 2) [12]. Jumlah total sampel yang digunakan sebanyak 8 botol. Masing-masing sediaan disimpan selama 2 minggu dalam kelompok perlakuan yang berbeda, yaitu :

a) Kelompok I : sediaan suspensi ibuprofen sebelum dilakukan perlakuan suhu penyimpanan.

b) Kelompok II : sebanyak $30 \mathrm{~mL}$ sediaan suspensi ibuprofen disimpan pada suhu kamar $25-27^{\circ}$ $\mathrm{C}$, diamati suhunya menggunakan termometer.

c) Kelompok III : sebanyak $30 \mathrm{~mL}$ sediaan suspensi ibuprofen disimpan pada lemari pendingin suhu sejuk $8-15^{\circ} \mathrm{C}$, diamati suhunya menggunakan termometer.

d) Kelompok IV : sebanyak $30 \mathrm{~mL}$ sediaan suspensi ibuprofen disimpan pada lemari pendingin suhu $4-6^{\circ} \mathrm{C}$, diamati suhunya menggunakan termometer. 


\section{Penetapan Kadar Sampel}

Preparasi pengukuran sediaan suspensi Ibuprofen yaitu dipipet sebanyak $0,625 \mathrm{~mL}$ setara dengan 12,5 mg Ibuprofen dimasukkan dalam labu takar $25 \mathrm{~mL}$, ditambahkan larutan fase gerak hingga tanda meniskus dan disaring menggunakan mikrofilter $0,22 \mu \mathrm{m}$. Setiap sampel uji diambil $2 \mathrm{~mL}$ dimasukkan ke dalam botol vial, lalu disonikasi selama 10 menit. Kemudian sampel diinjeksikan pada HPLC dengan masing-masing sampel dilakukan replikasi sebanyak 3 kali. Pengujian kadar sampel dilakukan pada hari ke-0, 7, dan 14 terhitung dari awal perlakuan suhu penyimpanan. Kadar suspensi Ibuprofen menurut literatur adalah tidak kurang dari 97,0\% dan tidak lebih dari 103,0\% [13].

\subsection{Analisis Data}

Metode yang digunakan dalam penelitian ini adalah metode eksperimental. Dimana penelitian ini dilakukan di Laboratorium Kimia Farmasi dan Laboratorium Instrumen Fakultas Ilmu Kesehatan Universitas Muhammadiyah Pekajangan Pekalongan pada bulan Mei hingga Juli 2021. Pengambilan data penelitian ini dilakukan pada masa penyimpanan suhu yang selanjutnya dianalisis menggunakan alat instrumen HPLC. Data yang diperoleh berupa kadar ibuprofen yang dimati menggunakan analisis regresi linier.

\section{HASIL DAN PEMBAHASAN}

\subsection{Kurva Baku Ibuprofen}

Pada penentuan panjang gelombang maksimum ibuprofen dibuat larutan baku induk ibuprofen, larutan seri konsentrasi ibuprofen, penentuan panjang gelombang maksimum, dan pembuatan kurva baku ibuprofen. Penentuan panjang gelombang maksimum Ibuprofen menggunakan larutan seri konsentrasi 100 dan $500 \mu \mathrm{g} / \mathrm{mL}$. Panjang gelombang maksimum dihasilkan oleh larutan yang memiliki puncak gelombang tertinggi. Penelitian ini diperoleh serapan panjang gelombang maksimum ibuprofen dari larutan konsentrasi 100 dan $500 \mu \mathrm{g} / \mathrm{mL}$ sebesar 223,5 nm. Penentuan linearitas kurva kalibrasi standar ibuprofen dengan larutan seri konsentrasi $100,200,300,400$, dan $500 \mu \mathrm{g} / \mathrm{mL}$ pada panjang gelombang $223,5 \mathrm{~nm}$ disajikan pada tabel I.

Tabel I. Luas Area Standar Ibuprofen

\begin{tabular}{ccc}
\hline $\begin{array}{c}\text { Konsentrasi } \\
(\mathbf{p p m})\end{array}$ & $\begin{array}{c}\text { Waktu } \\
\text { Retensi }(\mathbf{R t})\end{array}$ & Area Under Curve (AUC) \\
\hline 100 & 2,638 & 72.661 \\
200 & 2,648 & 481.979 \\
300 & 2,561 & 878.569 \\
400 & 2,661 & 1.233 .092 \\
500 & 2,545 & 1.680 .928 \\
\hline
\end{tabular}

Pembuatan kurva baku Ibuprofen dalam penelitian ini yaitu mencari regresi linier larutan seri konsentrasi 100, 200, 300, 400, dan $500 \mu \mathrm{g} / \mathrm{mL}$ menggunakan data AUC (area under curve) yang dihasilkan setelah diinjeksikan dalam sistem HPLC dengan laju alirnya adalah $1 \mathrm{~mL} / \mathrm{min}$ dan volume injeksi yang digunakan $20 \mu \mathrm{L}$ pada panjang gelombang maksimum. Data puncak kromatogram dibuat kurva kalibrasi dan dihitung persamaan garis regresinya. Persamaan liniernya berupa $\mathrm{y}=\mathrm{bx}+\mathrm{a}$.Sebagai parameter adanya hubungan linier digunakan koefisien korelasi $r$ pada analisis regresi linear $y=a+b x$. Hubungan linear yang ideal jika nilai $b$ 
$=0$ dan $\mathrm{r}=+1$ atau -1 bergantung pada arah garis [9]. Kurva kalibrasi diperoleh dari hasil pengukuran luas area yang linier terhadap konsentrasi sehingga didapatkan persamaan regresi linier. Nilai $\mathrm{r}$ yang diperoleh mendekati 1 dengan a negatif karena kurva kalibrasi ibuprofen berada dibawah garis linier. Persamaan regresi linier yang diperoleh $y=3967,75 x-320888$ dengan nilai $\mathrm{R}$ square $\left(\mathrm{R}^{2}\right)=0,9989$ dapat dilihat pada gambar 2 .

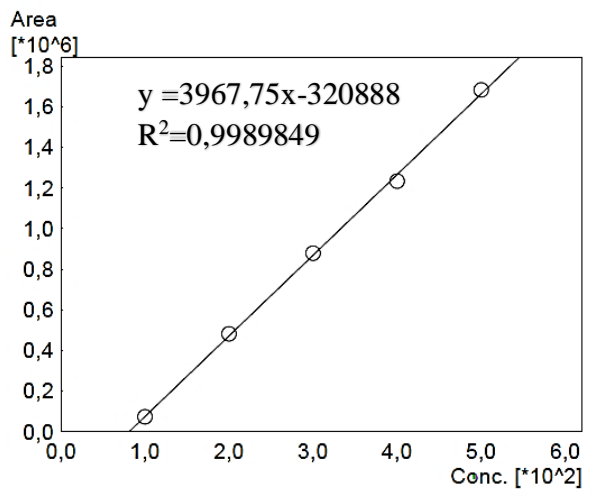

\section{Gambar 2. Kurva Kalibrasi Standar Ibuprofen}

\subsection{Kadar Suspensi Ibuprofen}

Pengukuran kadar ibuprofen berdasarkan perbedaan suhu penyimpanan yaitu tanpa perlakuan suhu, suhu kamar $\left(25-27^{\circ} \mathrm{C}\right)$, suhu sejuk $\left(8-15^{\circ} \mathrm{C}\right)$, dan suhu dingin $\left(4-6^{\circ} \mathrm{C}\right)$. Selain itu, pengukuran kadar dilakukan sebelum masa penyimpanan suhu, hari ke-7 dan hari ke-14 waktu simpan. Sampel yang digunakan dalam penelitian ini terdiri dari 2 jenis, yaitu suspensi ibuprofen merk generik (sampel 1) dan suspensi ibuprofen merk dagang (sampel 2).

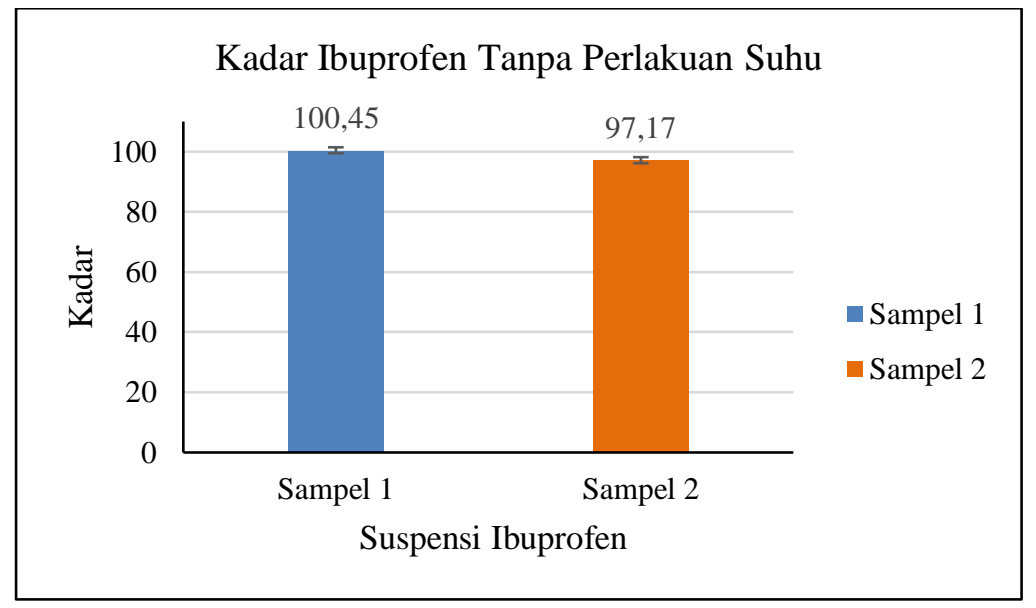

Gambar 3. Grafik Kadar Ibuprofen Tanpa Perlakuan Suhu

Kadar ibuprofen sebelum dilakukan masa simpan dapat dilihat pada gambar 3. Kadar sampel 1 sebelum masa simpan dilakukan ialah 100,45 mg sesuai dengan kadar yang tertera pada etiket, sedangkan kadar ibuprofen pada sampel 2 ialah 97,17 mg dimana kurang dari $100 \mathrm{mg}$. Kadar yang diperoleh pada sampel 1 dan 2 secara berurutan prosentasenya 100,45\% dan 97,17\%. Prosentase kadar ini sesuai dengan literatur yaitu tidak kurang dari $97 \%$ dan tidak lebih dari $103 \%$ [13]. 


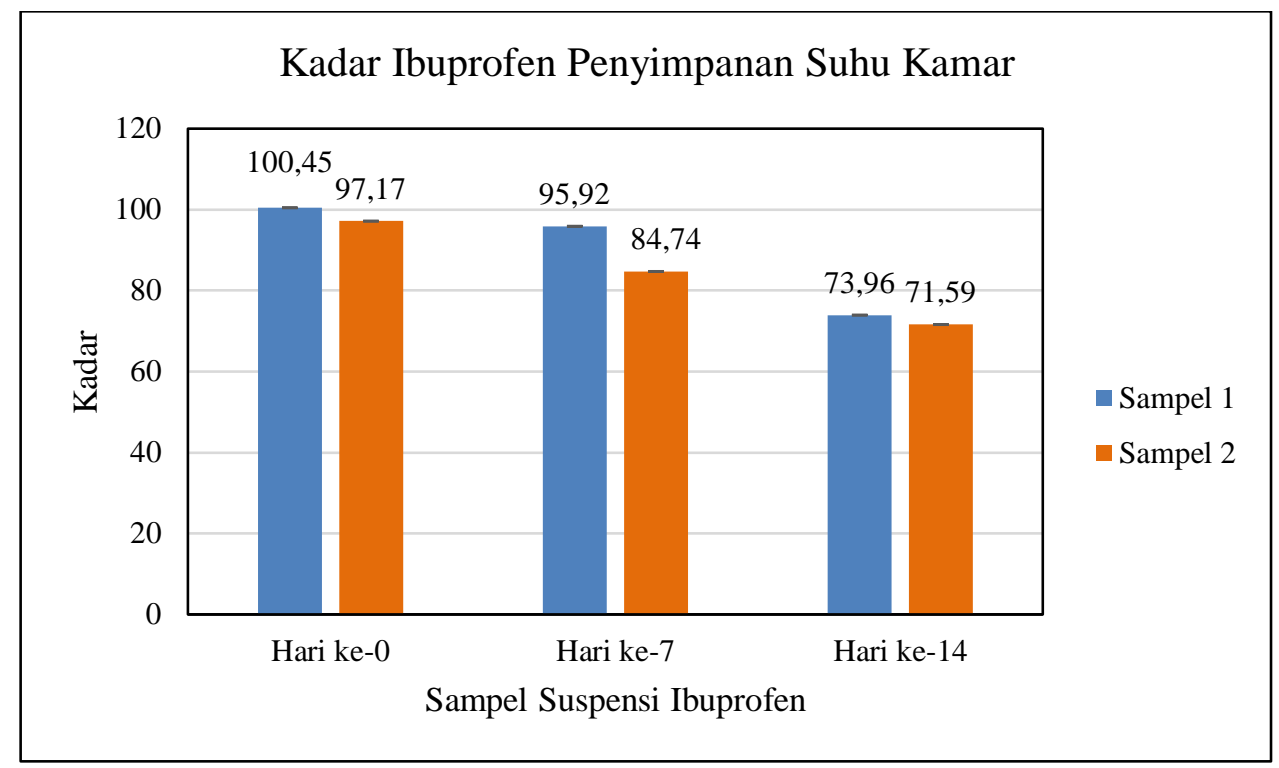

Gambar 4. Grafik Kadar Ibuprofen Penyimpanan Suhu Kamar

Grafik gambar 4 menunjukkan penurunan kadar ibuprofen selama masa simpan pada suhu kamar. Sampel 1 hari ke-7 mengalami penurunan kadar sebesar 5,2 mg dari kadar awal 100,45 mg menjadi 95,92 mg dan pada hari ke-14 menjadi 73,96 mg dengan penurunan kadar sebesar 26,49 mg. Pada sampel 2 hari ke-7 terjadi penurunan kadar 12,43 mg dari 97,17 mg menjadi 84,74 mg dan pada hari ke-14 kadarnya menjadi 71,59 mg dengan penurunan kadar 25,58 mg. Perubahan secara fisik dan kimia dapat mempengaruhi stabilitas sediaan. Perubahan ini dapat dilihat secara organoleptis, homogenitas partikel, dan endapan [8]. Suspensi ibuprofen penyimpaan suhu kamar secara fisik mulai terjadi pengendapan partikel, namun masih dapat terdispersi kembali saat pengocokan. Adanya zat lain yang masuk dalam kemasan seperti udara menyebabkan terjadinya penurunan efektivitas ibuprofen sehingga kadar obat dalam sediaan mulai turun seiring berjalannya masa penyimpanan.

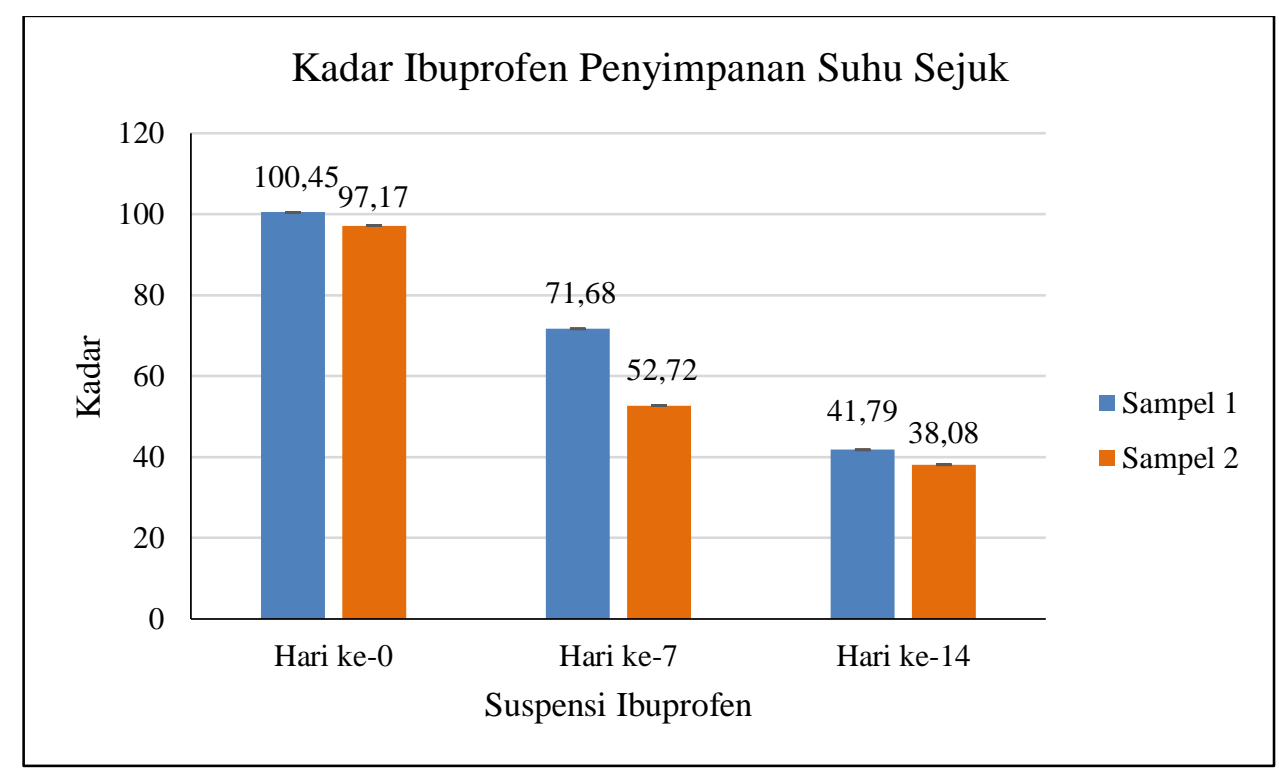

Gambar 5. Grafik Kadar Ibuprofen Penyimpanan Suhu Sejuk 
Pada penyimpanan suhu sejuk menunjukkan adanya penurunan kadar selama masa penyimpanan yang dapat dilihat pada gambar 5. Sampel 1 hari ke-7 mengalami penurunan kadar sebesar 28,77 mg dari kadar awal 100,45 mg menjadi 71,69 mg dan pada hari ke-14 menjadi $52,72 \mathrm{mg}$ dengan kadar yang turun sebesar $47,73 \mathrm{mg}$. Pada sampel 2 hari ke-7 terjadi penurunan kadar 55,38 mg dari 97,17 mg menjadi 41,79 mg dan pada hari ke-14 kadarnya menjadi 38,08 mg dengan penurunan kadar 59,09 mg. Radiasi cahaya, udara, dan kelembapan merupakan faktor untuk menentukan kestabilan sediaan [14]. Udara berperan besar sebagai kontaminan saat penyimpanan sampel setelah kemasan dibuka.

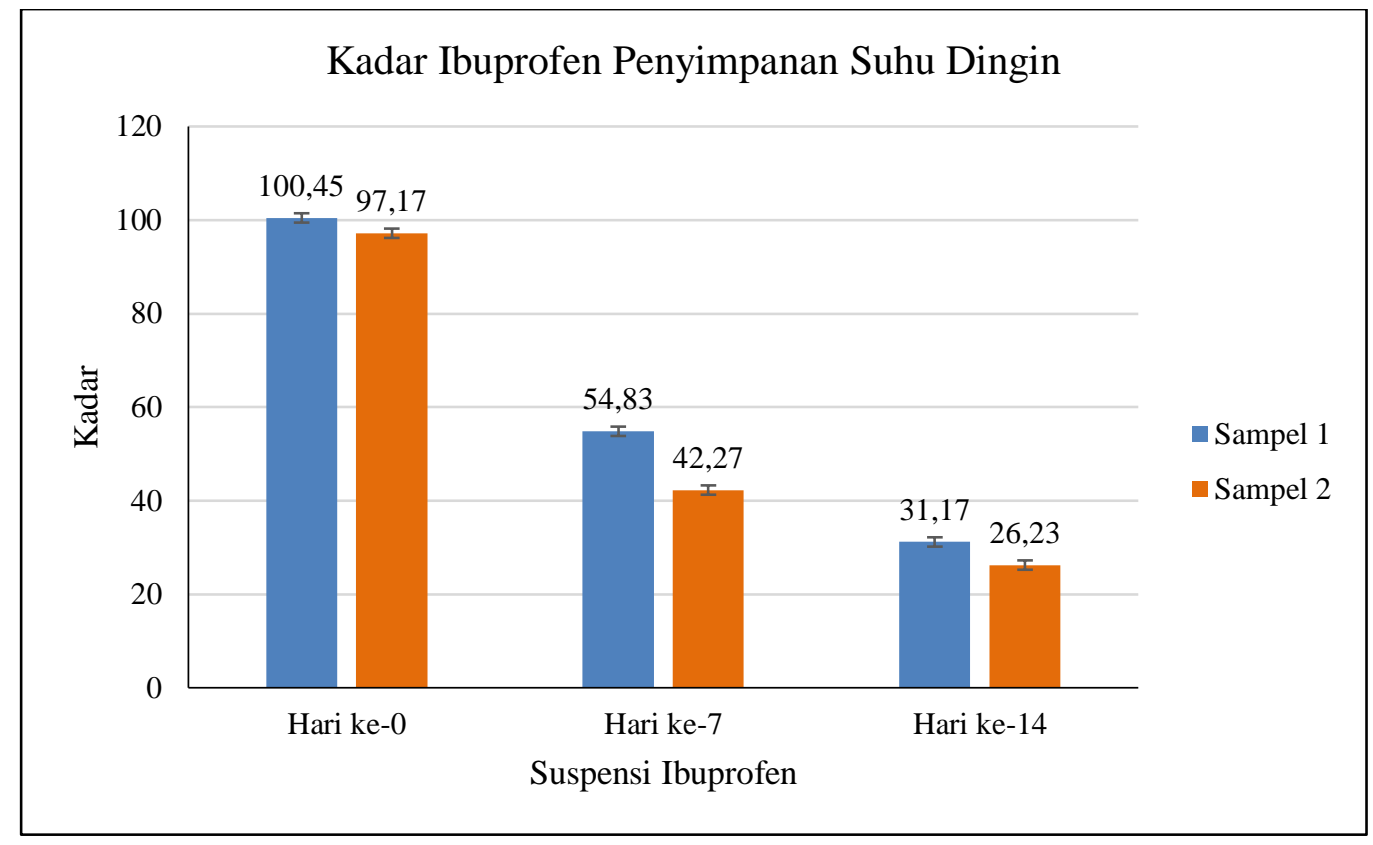

Gambar 6. Grafik Kadar Ibuprofen Penyimpanan Suhu Sejuk

Berdasarkan grafik gambar 6, sampel 1 hari ke-7 mengalami penurunan kadar sebesar 45,71 mg dari kadar awal 100,45 mg menjadi 54,83 mg dan pada hari ke-14 menjadi 31,17 mg dengan kadar yang turun sebesar 69,37 mg. Pada sampel 2 hari ke-7 terjadi penurunan kadar 54,87 mg dari 97,17 mg menjadi 42,30 mg dan pada hari ke-14 kadarnya menjadi 26,23 mg dengan penurunan kadar 70,94 mg. Peningkatan dan penurunan suhu penyimpanan berpengaruh terhadap dekomposisi kimia suatu obat [15]. Ibuprofen yang ketika mengendap partikelnya menjadi padatan kristal yang sulit didispersikan kembali. Sediaan suspensi ibuprofen yang disimpan pada suhu dingin dapat mengalami pengendapan sehingga partikel obat sulit terdispersi kembali setelah pengocokan (caking). Partikel yang mengendap ini adalah ibuprofen yang terdekomposisi menjadi kristal ibuprofen.

Tabel II. Kadar Ibuprofen

\begin{tabular}{lcccccc}
\hline Suhu & \multicolumn{3}{c}{ Sampel 1 } & \multicolumn{3}{c}{ Sampel 2 } \\
\cline { 2 - 7 } penyimpanan & Hari ke-0 & Hari ke-7 & Hari ke-14 & Hari ke-0 & Hari ke-7 & Hari ke-14 \\
\hline Suhu kamar & & 95,92 & 73,96 & & 84,74 & 71,59 \\
Suhu sejuk & 100,45 & 71,68 & 41,79 & 97,17 & 52,72 & 38,08 \\
Suhu dingin & & 54,38 & 31,17 & & 42,30 & 26,23 \\
\hline
\end{tabular}


Faktor suhu penyimpanan sediaan farmasi berpengaruh terhadap kadar obat yang terkandung dalam sediaan yang disajikan pada tabel II. Sediaan suspensi ibuprofen yang digunakan sebagai sampel penelitian ini menghasilkan reaksi penurunan kadar yang bervariasi pada setiap suhu. Penurunan kadar cukup signifikan pada penyimpanan suhu sejuk dan dingin, berbeda dengan penurunan kadar pada penyimpanan suhu kamar yang relatif lebih kecil.

\section{KESIMPULAN}

Perbedaan suhu berpengaruh pada kadar suspensi ibuprofen selama masa penyimpanan. Pengaruh suhu penyimpanan ditunjukkan dengan adanya penurunan kadar sediaan. Penurunan kadar pada penyimpanan suhu kamar $\left(25-27^{\circ} \mathrm{C}\right)$ sebesar 5,2 sampai $26,49 \mathrm{mg}$, pada penyimpanan suhu sejuk $\left(8-15^{\circ} \mathrm{C}\right)$ sebesar 28,77 sampai $59,09 \mathrm{mg}$, dan pada penyimpanan suhu dingin (4-6 ${ }^{\circ} \mathrm{C}$ ) sebesar 45,71 sampai 70,94 mg. Data penurunan kadar tersebut menunjukkan sediaan suspensi ibuprofen lebih stabil disimpan pada suhu kamar.

\section{DAFTAR PUSTAKA}

[1] Cahyaningrum, E. D., \& Putri, D, Perbedaan Suhu Tubuh Anak Demam Sebelum dan Setelah Kompres Bawang Merah. MEDISAINS: Jurnal Ilmiah Ilmu-Ilmu Kesehatan, 15(2), 66-74, 2017 [Online] Available http://jurnalnasional.ump.ac.id/index.php/medisains/article/view/1642

[2] Lubis, I. N. D., dan Lubis, C. P, Penanganan Demam pada Anak. Sari Pediatri, 12(6), 409418, 2011 [Online] Available https://saripediatri.org/index.php/saripediatri/article/view/479

[3] Febrianti, R. V., \& Wahyuningsih, I, Ibuprofen-Polivinil Pirolidon (PVP) Pada Tikus Putih Jantan. Pharmaciana, 3(2), 29-36, 2013 [Online] Available http://journal.uad.ac.id/index.php/PHARMACIANA/article/view/428

[4] Lestari, P. M, Karakteristik fisik nanopartikel ibuprofen. Skripsi, Fakultas Farmasi dan Sains Universitas Muhammadiyah Prof. Dr. Hamka Jakarta, 2018 [Online] Available http://simakip.uhamka.ac.id/download?type=penelitianlaporan\&id=103\&nomor=1

[5] Maryam, S., Taurina, W., dan Fahrurroji, A, Formulasi dan Evaluasi Stabilitas Fisik Suspensi Ibuprofen dengan Menggunakan Carbopol 934 sebagai Bahan Pensuspensi. Skripsi, Program Studi Farmasi Fakultas Kedokteran Universitas Tanjungpura Pontianak, 2013 [Online] Available https://jurnal.untan.ac.id/index.php/jmfarmasi/article/view/3074

[6] Asyikin, A, Studi Implementasi Sistem Penyimpanan Obat Berdasarkan Standar Pelayanan Kefarmasian Di Apotek Sejati Farma Makassar. Media Farmasi, 14(1) 29-30, 2018 [Online] Available http://journal.poltekkesmks.ac.id/ojs2/index.php/mediafarmasi/article/view/87

[7] Rachmawati, S., dan Ramdanawati, Analisis Sefadroksil Dalam Suspensi Kering dan Degradasinya pada Suhu yang Berbeda dengan Menggunakan Metode KCKT. Jurnal Farmasi Galenika, 6(1) 43-52, 2019 [Online] Available https://docplayer.info/179156439- 
Analisis-sefadroksil-dalam-suspensi-kering-dan-degradasinya-pada-suhu-yang-berbedamenggunakan-metode-kckt.html

[8] Wardani, P. M, Uji Stabilitas Fisik dan Kimia Sediaan Sirup Rekonstitusi yang Mengandung Tiamfenikol. Skripsi, Fakultas Farmasi Universitas Muhammadiyah Purwokerto, 4-15, 2016 [Online] Available http://repository.ump.ac.id/4770/

[9] Susanti, M. dan Dachriyanus, Kromatografi Cair Kinerja Tinggi, 2017, Sumatera : LPTIK Universitas Andalas.

[10] Romsiah, dan Yolanda, E, Validasi Metode dan Penetapan Kadar Ibuprofen Tablet Generik dan Nama Dagang secara Kromatografi Cair Kinerja Tinggi (KCKT). Jurnal Ilmiah Bakti Farmasi, $\quad$ 18(2), $\quad 55-60, \quad 2017 \quad$ [Online] Available https://ejournal.stifibp.ac.id/index.php/jibf/article/view/27

[11] Supardi, S., dan Surahman, Metodologi Penelitian untuk Mahasiswa Farmasi, 2014, Jakarta : CV. Trans Info Media.

[12] Sopian, A. M, Pengaruh Lokasi dan Promosi Terhadap Keputusan Pembelian (Studi Kasus Pada Konsumen Kedai Kopi Euy Kota Bandung). Skripsi, Fakultas Ekonomi dan Bisnis Unpas Bandung, 2017 [Online] Available http://repository.unpas.ac.id/31691/

[13] Anonim, Farmakope Indonesia Edisi VI, Departemen Kesehatan Republik Indonesia, 2020, Jakarta.

[14] Umar, S., Selfia, M., dan Azhar, R, Studi Stabilitas Fisika dan Kimia Dispersi Padat Ketoprofen-Urea. Jurnal Farmasi Higea, 6(2), 162-173, 2014 [Online] Available https://www.jurnalfarmasihigea.org/index.php/higea/article/view/108

[15] Hameed, G.S., Mohamed, M.B.M., and Mohamed, Y.A, Effect of Storage Condition on The Physicochemical Properties of Ibuprofen. International Journal of Pharmaceutical Research, 12(2), 3038-304, $2020 \quad$ [Online] Available https://www.researchgate.net/publication/347928991_Effect_of_storage_condition_on_ the physicochemical properties of ibuprofen 